\title{
Prognostic Characteristics of Operated Breast Cancer Patients with Second Primary Lung Cancer: A Retrospective Study
}

\section{Yan Wang (D) \\ Jialong Li \\ Shuai Chang \\ Yingxian Dong \\ Guowei Che}

Department of Thoracic Surgery, West China Hospital, Sichuan University, Chengdu, 6I004I, People's Republic of China
Correspondence: Guowei Che Department of Thoracic Surgery, West China Hospital, Sichuan University, Chengdu, 61004I, People's Republic of China

Email cheguowei_hx@aliyun.com
Background and Purpose: The number of breast cancer patients with second primary lung cancer is increasing year by year. The aim of this study was to explore the prognostic characteristics of these multiple primary breast and lung cancer patients.

Methods: Operated breast cancer patients with subsequent lung cancer who were admitted to our hospital from January, 2010 to August, 2020 were retrospectively analyzed. The univariate and multivariate Cox regression analyses were conducted to explore the prognostic risk factors of such patients. Meanwhile, the propensity score match (PSM) method was applied to compare the prognosis between lung cancer patients with and without the history of breast cancer.

Results: A total of 137 cases were included and most of them (94.9\%) were asynchronous multiple primary carcinomas. The median interval between the diagnoses of breast cancer and lung cancer was 60 months (2-456 months), median age at the diagnosis of breast cancer was 49.5 (28-81) years old and median age at the diagnosis of lung cancer was 58 (31-84) years old. Univariate and multivariate Cox regression analysis indicated that poor differentiation [hazard ratio $(\mathrm{HR})=6.372,95 \%$ confidence interval $(\mathrm{CI}): 2.441-16.633, \mathrm{P}<0.001$ ] and pTNM stage III/IV (HR=5.830, 95\% CI: 2.295-14.813, $\mathrm{P}<0.001)$ of lung cancer were independent prognostic risk factors for these patients. Before and after the PSM, the overall survival (OS) of lung cancer patients with breast cancer was significantly worse than that of single primary lung cancer patients $(\mathrm{P}<0.001, \mathrm{P}=0.002)$.

Conclusion: Differentiation status and pTNM stage were independent prognostic factors in operated breast cancer patients with second primary lung cancer. Meanwhile, the prognosis of this group of patients was worse than single primary lung cancer patients, which indicated that the medical history of breast cancer was also a prognostic risk factor of female lung cancer patients.

Keywords: breast cancer, second primary lung cancer, prognosis

\section{Introduction}

In the past 20 years, great progress has been made in the early diagnosis, surgical treatment and chemoradiotherapy of breast cancer. Thus, the survival of breast cancer patients has been significantly improved. Due to the prolonged survival time of patients, the risk of subsequent primary malignancies has also increased. It has been widely demonstrated that some anti-tumor treatment such as the chemotherapy and radiotherapy would also increase the risk of second primary malignancies. $^{1-3}$ According to the information provided by a study including more than 500,000 breast cancer patients, female breast cancer patients were 
obviously more likely to develop a second primary tumor than the general population. In addition, this phenomenon would become more obvious when the survival time increased. Patients who lived longer than ten years showed about forty-percent increased risk of second primary tumors, such as the esophageal cancer, soft tissue sarcoma and lung cancer. ${ }^{4}$

Lung cancer in one of the common second primary malignancies among breast cancer patients. Previous literatures reported that the five-year survival rate of breast cancer patients combined with second primary lung cancer is less than $20 \%{ }^{5}$ Therefore, finding reliable and effective prognostic factors of this group of patients may greatly contribute to the evaluation of prognosis and formulation of treatment strategy. However, few studies have identified the prognostic risk factors of multiple primary breast and lung cancer patients up to now.

Therefore, the aim of this study was to explore prognostic characteristics of operated breast cancer patients with second primary lung cancer, which might help with the evaluation of prognosis and formulation of therapy strategy.

\section{Materials and Methods Study Design}

This is a retrospective single-center study. This study was approved by the regional committee of Sichuan University West China Hospital (ID: 2020-250). Written informed consent for the use and storage of information from the hospital database was obtained from each patient.

\section{Patient Selection}

The inclusion criteria for multiple primary cancer patients were as follows: 1) female breast cancer patients with second primary lung cancer who were admitted to West China Hospital, Sichuan University from January, 2010 to August, 2020;2) the primary breast cancer and lung cancer were both pathologically diagnosed; 3) patients received the surgical therapy for breast cancer; 4) without the history of other malignancies; 5) the age at the diagnosis of breast cancer was greater or equal to 18 years old. Besides, the inclusion criteria for single primary lung cancer patients were as follows: 1) female lung cancer patients who were admitted to our hospital from January, 2014 to December, 2019; 2) the lung cancer was pathologically diagnosed and the operation was received; 3 ) the age at the diagnosis of lung cancer was greater or equal to 18 years old; 4) without the history of other malignancies; 5) the survival information was obtained.

The exclusion criteria were as follows: 1) primary tumors in other locations were found or suspected during the follow-up period; 2) pulmonary metastasis of breast cancer.

\section{Data Collection}

Breast cancer-related data included the age and menstrual status (menopause or premenopause) at the diagnosis, tumor location, tumor stage, estrogen receptor (ER), progesterone receptor (PR), human epidermal growth factor receptor-2 (HER-2) and therapy strategy. Positive ER and PR were defined as nuclear staining positive tumor cells accounted for $\geq 1 \%{ }^{6}$ The expression status of HER-2 was defined according to the score system recommended by the American Society of Clinical Oncology (ASCO) and College of American Pathologists (CAP). In detail, negative HER-2 was defined as immunohistochemical staining (IHC) 0 or $(+)$ and positive HER-2 was defined as the IHC staining $(+++)$. The fluorescence in situ hybridization (FISH) was conducted when the IHC staining was $(++)$ and the positive and negative HER-2 expression was defined as the FISH (+) and FISH (-), respectively. ${ }^{7}$ The pathological tumor-node-metastasis (pTNM) staging standard recommended by the American Joint Committee on Cancer (AJCC) (eighth edition) was adopted for breast cancer staging. ${ }^{8}$

Lung cancer-related data included the age at the diagnosis of lung cancer, history of smoking, family history of malignancies, comorbidity such as the hypertension and diabetes, tumor location, histopathologic subtype, differentiation degree, tumor stage and therapy strategy. Family history of malignancies was defined as at least one firstdegree relative who was diagnosed with a malignant tumor. The pTNM staging standard recommended by the AJCC and Union for International Cancer Control (UICC) (eighth edition) was adopted for lung cancer staging. ${ }^{9}$

According to the interval between the diagnosis of breast cancer and lung cancer, patients were divided into simultaneous ( $<6$ months) and metachronous ( $\geq 6$ months) double primary cancer patients. ${ }^{10}$ The follow-up was conducted through the telephone, outpatient or inpatient medical record, starting from the date of lung cancer diagnosis and ending on November 1, 2020 or the date of death. Overall survival (OS) was defined as the interval from the 
Table I Breast Cancer Related Clinicopathological Characteristics

\begin{tabular}{|c|c|}
\hline Parameters & n (\%) \\
\hline Age at the diagnosis of breast cancer (years) & $49.5(28-8 I)$ \\
\hline$<40$ & $17(12.4)$ \\
\hline $40-49$ & $51(37.2)$ \\
\hline $50-59$ & $47(34.3)$ \\
\hline $60-69$ & $16(11.7)$ \\
\hline$\geq 70$ & $6(4.4)$ \\
\hline \multicolumn{2}{|l|}{ Family history of malignancies } \\
\hline With & $30(24.0)$ \\
\hline Without & $95(76.0)$ \\
\hline \multicolumn{2}{|l|}{ Menstrual status at the diagnosis of breast cancer } \\
\hline Menopause & $71(52.6)$ \\
\hline Premenopause & $64(47.4)$ \\
\hline \multicolumn{2}{|l|}{ Location of breast cancer } \\
\hline Left & $60(50.4)$ \\
\hline Right & $59(49.6)$ \\
\hline \multicolumn{2}{|l|}{ pT stage of breast cancer } \\
\hline TI & $55(78.6)$ \\
\hline $\mathrm{T} 2-4$ & $15(21.4)$ \\
\hline \multicolumn{2}{|l|}{$\mathrm{pN}$ stage of breast cancer } \\
\hline No & $31(70.5)$ \\
\hline NI-3 & $13(29.5)$ \\
\hline \multicolumn{2}{|l|}{ pM stage of breast cancer } \\
\hline Mo & $134(98.5)$ \\
\hline MI & $2(1.5)$ \\
\hline \multicolumn{2}{|l|}{ PTNM stage of breast cancer } \\
\hline I/II & $34(81.0)$ \\
\hline III/IV & $8(19.0)$ \\
\hline \multicolumn{2}{|l|}{ Expression status of ER } \\
\hline Positive & $35(76.1)$ \\
\hline Negative & II (23.9) \\
\hline \multicolumn{2}{|l|}{ Expression status of PR } \\
\hline Positive & $30(65.2)$ \\
\hline Negative & $16(34.8)$ \\
\hline \multicolumn{2}{|l|}{ Expression status of HER-2 } \\
\hline Positive & II (23.9) \\
\hline Negative & $35(76.1)$ \\
\hline \multicolumn{2}{|l|}{ Chemotherapy } \\
\hline With & $92(67.6)$ \\
\hline Without & $44(32.4)$ \\
\hline \multicolumn{2}{|l|}{ Radiotherapy } \\
\hline With & $55(40.4)$ \\
\hline Without & 81 (59.6) \\
\hline
\end{tabular}

(Continued)
Table I (Continued).

\begin{tabular}{|l|l|}
\hline Parameters & n (\%) \\
\hline $\begin{array}{l}\text { Median interval between the diagnoses of breast } \\
\text { cancer and lung cancer }\end{array}$ & $60(2-456)$ \\
\hline $\begin{array}{l}\text { Simultaneous (<6 months) } \\
\text { Metachronous ( } \geq 6 \text { months) }\end{array}$ & $\begin{array}{l}7(5.1) \\
130(94.9)\end{array}$ \\
\hline
\end{tabular}

Abbreviations: ER, estrogen receptor; PR, progesterone receptor; HER-2, human epidermal growth factor receptor-2.

diagnosis of lung cancer to the endo of follow-up or the death of the patient.

\section{Statistical Analysis}

All statistical analysis was conducted by SPSS 22.0 software. The categorical and continuous variables were presented as the frequencies with percentages and mean \pm standard deviation (SD), respectively. The chi-square test or Fisher's exact test was used for the comparison of comparison of categorical variables. The univariate and multivariate Cox regression analyses were performed for prognostic factors and variables with a $\mathrm{P}$ value $<0.10$ were enrolled in the multivariate regression analyses. The propensity score match (PSM) with a 1:1 ratio was performed to compare the prognosis between lung cancer patients with and without the history of breast cancer using the nearest matching method with a caliper width equal to 0.2 and several parameters were matched including the age, comorbidity, pTNM stage, differentiation degree and pathological subtype of lung cancer. Meanwhile, we used the standardized percentage bias of factors to evaluate the effect of matching. Survival curves were estimated via KaplanMeier analysis, and the survival differences between groups were assessed via the Log rank test. Besides, the Cox regression analysis among the matched patients were also conducted. All statistical tests were two-sided and $\mathrm{P}$-values $<0.05$ were considered statistically significant.

\section{Results}

\section{Basic Characteristics of Enrolled Patients}

A total of 137 multiple primary cancer patients were enrolled in this study, with the median interval between the diagnoses of breast cancer and lung cancer of 60 (2456) months, median age at the diagnosis of breast cancer of 49.5 (28-81) years old and median age at the diagnosis 
Table 2 Lung Cancer Related Clinicopathological and Prognostic Characteristics

\begin{tabular}{|c|c|}
\hline Parameters & n (\%) \\
\hline Median age at the diagnosis of lung cancer (years) & $58(3 \mid-84)$ \\
\hline$<40$ & $6(4.4)$ \\
\hline $40-49$ & $25(18.2)$ \\
\hline $50-59$ & $42(30.7)$ \\
\hline $60-69$ & $43(3 \mid .4)$ \\
\hline$\geq 70$ & $21(15.3)$ \\
\hline \multicolumn{2}{|l|}{ Smoking } \\
\hline With & I (0.7) \\
\hline Without & $136(99.3)$ \\
\hline \multicolumn{2}{|l|}{ Comorbidity } \\
\hline Hypertension & $19(13.9)$ \\
\hline Diabetes & $12(8.8)$ \\
\hline \multicolumn{2}{|l|}{ Location of lung cancer } \\
\hline Left & $56(40.9)$ \\
\hline Right & $73(53.3)$ \\
\hline Bilateral & $8(5.8)$ \\
\hline \multicolumn{2}{|l|}{ Relative position of breast and lung cancer } \\
\hline Ipsilateral & $64(53.8)$ \\
\hline Contralateral & $55(46.2)$ \\
\hline \multicolumn{2}{|l|}{ Pathological subtype of lung cancer } \\
\hline Adenocarcinoma & $123(89.8)$ \\
\hline Squamous cell carcinoma & $6(4.4)$ \\
\hline Small cell carcinoma & $2(1.4)$ \\
\hline Adenosquamous carcinoma & $3(2.2)$ \\
\hline Others & $3(2.2)$ \\
\hline \multicolumn{2}{|l|}{ Differentiation of lung cancer } \\
\hline Poor & $35(27.1)$ \\
\hline Moderate & $81(62.8)$ \\
\hline Well & $13(10.1)$ \\
\hline \multicolumn{2}{|l|}{ PT stage of lung cancer } \\
\hline $\mathrm{TI} / 2$ & $108(87.1)$ \\
\hline $\mathrm{T} 3 / 4$ & $16(12.9)$ \\
\hline \multicolumn{2}{|l|}{$\mathrm{pN}$ stage of lung cancer } \\
\hline No & $90(73.8)$ \\
\hline $\mathrm{NI} / 2 / 3$ & $32(26.2)$ \\
\hline \multicolumn{2}{|l|}{ PM stage of lung cancer } \\
\hline Mo & $102(80.3)$ \\
\hline MI & $25(19.7)$ \\
\hline \multicolumn{2}{|l|}{ PTNM stage of lung cancer } \\
\hline $\mathrm{I} / \mathrm{II}$ & $95(73.1)$ \\
\hline III/IV & $35(26.9)$ \\
\hline \multicolumn{2}{|l|}{ Surgical therapy } \\
\hline With & $103(79.2)$ \\
\hline Without & $27(20.8)$ \\
\hline
\end{tabular}

(Continued)
Table 2 (Continued).

\begin{tabular}{|l|l|}
\hline Parameters & n (\%) \\
\hline $\begin{array}{l}\text { Chemotherapy } \\
\text { With } \\
\text { Without }\end{array}$ & $22(16.9)$ \\
$108(83.1)$
\end{tabular}

of lung cancer of 58 (31-84) years old. Detailed breast cancer related and lung cancer related clinicopathological characteristics were presented in Tables 1 and 2. The survival information of 119 patients were obtained in our study and $94(79.0 \%)$ were alive, with median follow-up time of 20 (1-107) months.

Besides, for single primary lung cancer, 473 patients were enrolled with the median age of 59 (29-82) years old.

\section{Prognostic Factors of Multiple Primary Breast and Lung Cancer Patients}

According to the univariate analysis, the radiotherapy for breast cancer $(\mathrm{P}=0.035)$, poor differentiation $(\mathrm{P}<0.001)$, pT3/4 ( $\mathrm{P}=0.056)$, lymph node metastasis $(\mathrm{P}<0.001)$, distant metastasis $(\mathrm{P}<0.001)$ and pTNM III/IV stage of lung cancer $(\mathrm{P}<0.001)$ were potentially related with OS of multiple primary cancer patients. Then, the results of multivariate Cox regression analysis indicated that poor differentiation [hazard ratio $(\mathrm{HR})=6.372,95 \%$ confidence interval (CI): 2.441-16.633, $\mathrm{P}<0.001]$ and pTNM III/IV stage $(\mathrm{HR}=5.830,95 \% \mathrm{CI}: 2.295-14.813, \mathrm{P}<0.001)$ of lung cancer were independent prognostic risk factors in these patients (Table 3; Figures 1 and 2).

\section{Comparison of OS Between Lung Cancer Patients with and without Breast Cancer}

Before the PSM, significant differences of the pTNM stage and differentiation status of lung cancer between lung cancer patients with and without breast cancer were 
Table 3 Results of Univariate and Multivariate Cox Regression

\begin{tabular}{|c|c|c|c|c|c|c|}
\hline \multirow[t]{2}{*}{ Parameters } & \multicolumn{3}{|c|}{ Univariate } & \multicolumn{3}{|c|}{ Multivariate } \\
\hline & HR & $95 \% \mathrm{Cl}$ & $P$ value & HR & $95 \% \mathrm{Cl}$ & $P$ value \\
\hline Age $\geq 50$ (breast) & 1.288 & $0.568-2.921$ & 0.544 & & & \\
\hline Menopause & 1.224 & $0.542-2.763$ & 0.625 & & & \\
\hline Family history of malignancies & 1.188 & $0.472-2.989$ & 0.714 & & & \\
\hline PT2-4 of breast cancer & 0.412 & $0.052-3.256$ & 0.400 & & & \\
\hline pNI-3 of breast cancer & 1.780 & $0.108-29.285$ & 0.687 & & & \\
\hline PTNM III/IV of breast cancer & 1.992 & $0.492-8.074$ & 0.334 & & & \\
\hline Positive PR & 1.154 & $0.104-12.757$ & 0.907 & & & \\
\hline Positive HER-2 & 0.258 & $0.022-2.986$ & 0.278 & & & \\
\hline Chemotherapy for breast cancer & 0.680 & $0.305-1.515$ & 0.345 & & & \\
\hline Radiotherapy for breast cancer & 2.340 & $1.060-5.166$ & 0.035 & 1.795 & $0.782-4.120$ & 0.168 \\
\hline Interval (<5 years) & 0.665 & $0.293-1.508$ & 0.329 & & & \\
\hline Age $\geq 50$ (lung) & 1.697 & $0.58 \mathrm{I}-4.953$ & 0.333 & & & \\
\hline Location of lung cancer & $1.28 \mathrm{I}$ & $0.665-2.468$ & 0.459 & & & \\
\hline Pathological subtype of lung cancer (adenocarcinoma) & 0.560 & $0.210-1.497$ & 0.248 & & & \\
\hline Poor differentiation of lung cancer & 9.276 & $3.699-23.265$ & $<0.001$ & 6.372 & $2.44 I-16.633$ & $<0.001$ \\
\hline $\mathrm{pT} 3 / 4$ of lung cancer & 1.657 & $0.986-2.785$ & 0.056 & & & \\
\hline $\mathrm{pNI}-3$ of lung cancer & 27.488 & $6.342-119.144$ & $<0.001$ & & & \\
\hline pMI of lung cancer & 6.883 & $2.769-17.110$ & $<0.001$ & & & \\
\hline PTNM III/IV of lung cancer & 7.211 & $3.006-17.299$ & $<0.001$ & 5.830 & $2.295-14.813$ & $<0.001$ \\
\hline
\end{tabular}

Abbreviations: PR, progesterone receptor; HER-2, human epidermal growth factor receptor-2.

observed (Table 4). The Kaplan-Meier survival curve showed that the OS of lung cancer patients with breast cancer was significantly worse than that of single primary lung cancer patients $(\mathrm{P}<0.001)$ (Figure 3$)$.

After the PSM, no significant differences in the age, hypertension, diabetes, pTNM stage, differentiation status and pathological type were observed between the two

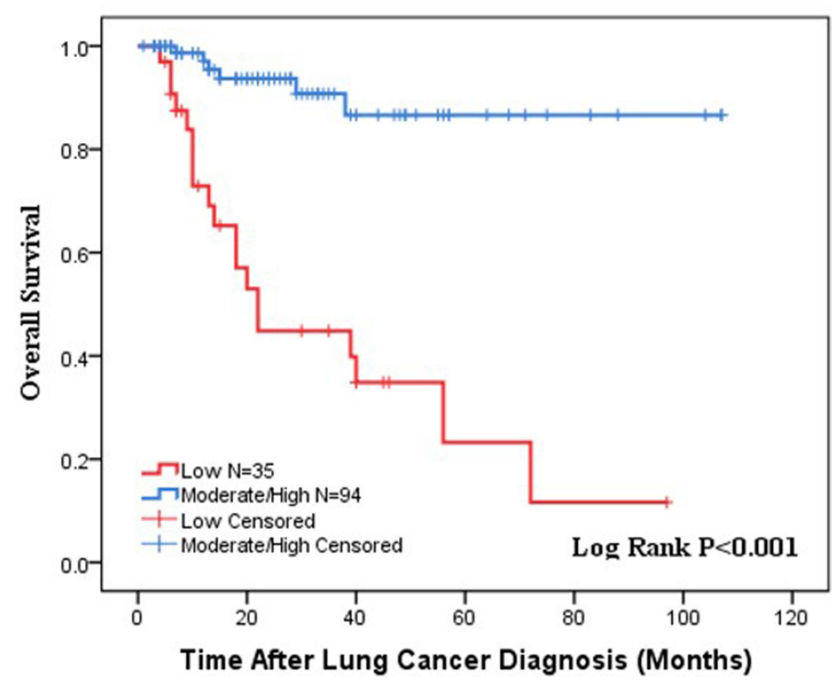

Figure I Kaplan-Meier survival curve showing the relationship between the differentiation status of lung cancer and overall survival. groups (Table 4). The Kaplan-Meier survival curve still revealed that the OS of multiple primary breast and lung cancer patients was significantly worse than that of single primary lung cancer patients $(\mathrm{P}<0.001)$ (Figure 4). Besides, the Cox regression analysis was also conducted among the 236 patients. The results indicated that the history of breast cancer $(\mathrm{HR}=3.507,95 \%$ CI: 1.819

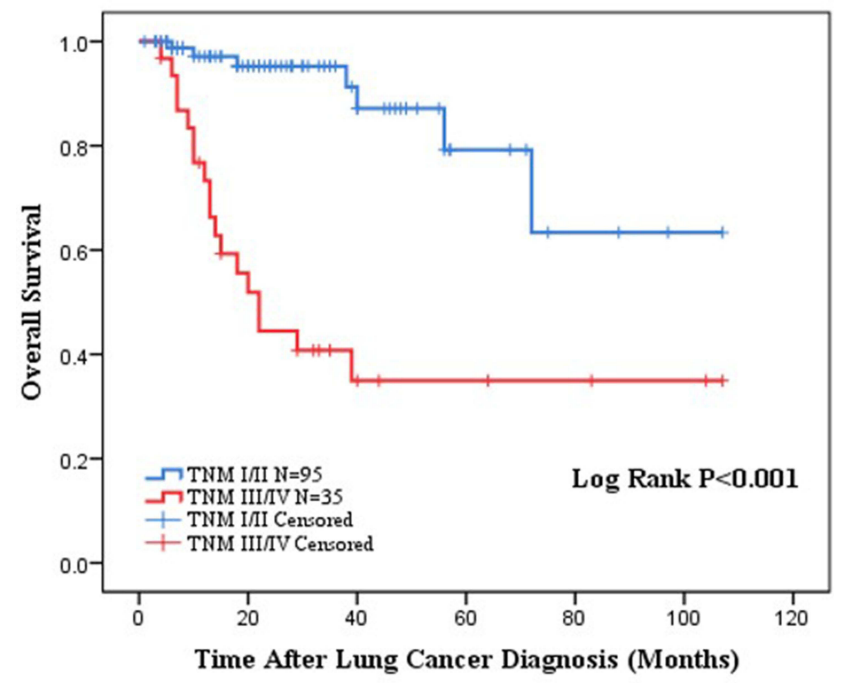

Figure 2 Kaplan-Meier survival curve showing the relationship between the PTNM stage of lung cancer and overall survival. 
Table 4 Comparison of Clinicopathological and Prognostic Characteristics Between Lung Cancer Patients with and without Breast Cancer

\begin{tabular}{|c|c|c|c|c|c|c|c|c|}
\hline \multirow[t]{2}{*}{ Parameters } & \multicolumn{3}{|c|}{ Before PSM } & \multicolumn{3}{|c|}{ After PSM } & \multicolumn{2}{|c|}{$\begin{array}{c}\text { Standard } \\
\text { Percentage } \\
\text { Bias }\end{array}$} \\
\hline & $\begin{array}{l}\text { With Breast } \\
\text { Cancer } \\
(n=119)\end{array}$ & $\begin{array}{l}\text { Without Breast } \\
\text { Cancer }(n=473)\end{array}$ & $P$ value & $\begin{array}{l}\text { With Breast } \\
\text { Cancer } \\
(n=I \mid 8)\end{array}$ & $\begin{array}{l}\text { Without Breast } \\
\text { Cancer }(n=|| 8)\end{array}$ & P value & Before & After \\
\hline Age, mean (SD) & $57.8 \pm 11.2$ & $58.1 \pm 10.7$ & 0.786 & $57.8 \pm 11.2$ & $56.2 \pm 10.8$ & 0.254 & -2.8 & 15.0 \\
\hline $\begin{array}{l}\text { Hypertension, n (\%) } \\
\text { With } \\
\text { Without }\end{array}$ & $\begin{array}{l}16(13.4) \\
103(86.6)\end{array}$ & $\begin{array}{l}77(16.3) \\
396(83.7)\end{array}$ & 0.448 & $\begin{array}{l}16(13.6) \\
102(86.4)\end{array}$ & $\begin{array}{l}\text { I3 (I I.0) } \\
105(89.0)\end{array}$ & 0.552 & -8.0 & 7.1 \\
\hline $\begin{array}{l}\text { Diabetes, n (\%) } \\
\text { With } \\
\text { Without }\end{array}$ & $\begin{array}{l}9(7.6) \\
110(92.4)\end{array}$ & $\begin{array}{l}18(3.8) \\
455(96.2)\end{array}$ & 0.079 & $\begin{array}{l}9(7.6) \\
109(92.4)\end{array}$ & $\begin{array}{l}8(6.8) \\
110(93.2)\end{array}$ & 0.801 & 16.2 & 3.7 \\
\hline $\begin{array}{l}\text { PTNM stage, n (\%) } \\
\text { I } \\
\text { II } \\
\text { III } \\
\text { IV }\end{array}$ & $\begin{array}{l}83(69.8) \\
5(4.2) \\
8(6.7) \\
23(19.3)\end{array}$ & $\begin{array}{l}361(76.3) \\
43(9.1) \\
47(9.9) \\
22(4.7)\end{array}$ & $<0.001$ & $\begin{array}{l}83(70.3) \\
5(4.2) \\
8(6.8) \\
22(18.7)\end{array}$ & $\begin{array}{l}80(67.8) \\
7(5.9) \\
16(13.5) \\
15(12.7)\end{array}$ & 0.223 & 31.1 & 2.4 \\
\hline $\begin{array}{l}\text { Differentiation of, } \\
\text { n (\%) } \\
\text { Poor } \\
\text { Moderate } \\
\text { Well }\end{array}$ & $\begin{array}{l}33(27.7) \\
75(63.0) \\
\text { II }(9.3)\end{array}$ & $\begin{array}{l}127(26.9) \\
257(54.3) \\
89(18.8)\end{array}$ & 0.039 & $\begin{array}{l}33(28.0) \\
74(62.7) \\
I I(9.3)\end{array}$ & $\begin{array}{l}36(30.5) \\
71(60.2) \\
I I(9.3)\end{array}$ & 0.908 & -16.3 & 4.1 \\
\hline $\begin{array}{l}\text { Pathological type, } \\
\text { n (\%) } \\
\text { Adenocarcinoma } \\
\text { Squamous cell } \\
\text { Small cell } \\
\text { carcinoma } \\
\text { Adenosquamous } \\
\text { carcinoma } \\
\text { Others }\end{array}$ & $\begin{array}{l}106(89.1) \\
5(4.2) \\
2(1.7) \\
3(2.5) \\
3(2.5)\end{array}$ & $\begin{array}{l}440(93.0) \\
19(4.0) \\
5(1.1) \\
5(1.1) \\
4(0.8)\end{array}$ & 0.374 & $\begin{array}{l}106(89.9) \\
5(4.2) \\
2(1.7) \\
3(2.5) \\
2(1.7)\end{array}$ & $\begin{array}{l}105(89.0) \\
4(3.4) \\
4(3.4) \\
2(1.7) \\
3(2.5)\end{array}$ & $0.88 I$ & 17.9 & -4.8 \\
\hline $\begin{array}{l}\text { Existentiality, n (\%) } \\
\text { Alive } \\
\text { Dead }\end{array}$ & $\begin{array}{l}94(79.0) \\
25(21.0)\end{array}$ & $\begin{array}{l}422(89.2) \\
51(10.8)\end{array}$ & 0.003 & $\begin{array}{l}93(78.8) \\
25(21.2)\end{array}$ & $\begin{array}{l}101(85.6) \\
17(14.4)\end{array}$ & 0.173 & - & - \\
\hline
\end{tabular}

Abbreviations: SD, standard deviation; PSM, propensity score match.

6.761, $\mathrm{P}<0.001)$, pTNM stage III/IV (HR $=5.211,95 \% \mathrm{CI}$ : 2.559-10.608, $\mathrm{P}<0.001)$ and poor differentiation $(\mathrm{HR}=6.627,95 \%$ CI: $3.005-14.616, \mathrm{P}<0.001)$ were independent prognostic factors for lung cancer patients.

\section{Discussion}

The current study identified the prognostic characteristics of operated breast cancer patients with second primary lung cancer by analyzing 137 cases from our medical center. The results indicated that poor differentiation $(\mathrm{HR}=6.372,95 \%$ confidence interval $\mathrm{CI}$ : $2.441-$ 16.633, $\mathrm{P}<0.001)$ and $\mathrm{pTNM}$ stage III/IV $(\mathrm{HR}=5.830$, 95\% CI: $2.295-14.813, \mathrm{P}<0.001)$ of lung cancer were independent prognostic risk factors for these patients. Meanwhile, we manifested that the OS of lung cancer patients with breast cancer was significantly worse than that of single primary lung cancer patients $(\mathrm{P}<0.001)$, which indicated that the medical history of breast cancer 


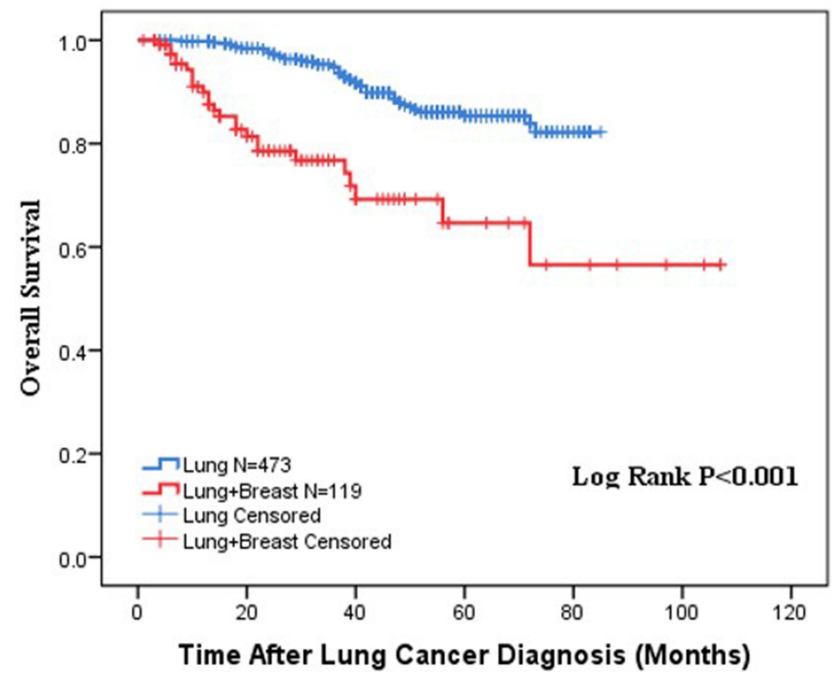

Figure 3 The comparison of overall survival between lung cancer patients with and without breast cancer before the propensity score match.

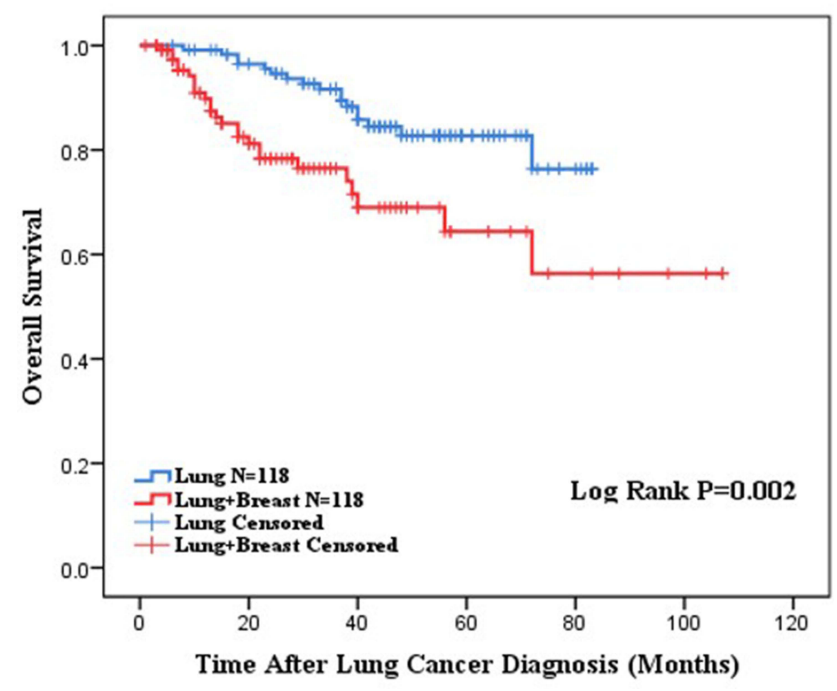

Figure 4 The comparison of overall survival between lung cancer patients with and without breast cancer after the propensity score match.

was a prognostic risk factor of female lung cancer patients, too.

Few studies have explored the prognostic characteristics of breast cancer patients with second primary lung cancer up to now. Wang et al conducted a research by analyzing 6269 cases from the SEER databases and manifested that the ER $(\mathrm{P}<0.001), \mathrm{PR}(\mathrm{P}<0.001)$, age at the diagnosis of lung cancer $(\mathrm{P}<0.001)$, pathological subtype of breast cancer $(\mathrm{P}=0.001)$, interval between the diagnoses of breast cancer and lung cancer $(\mathrm{P}<0.001)$, pathological subtype of lung cancer $(\mathrm{P}<0.001)$, differentiation degree $(\mathrm{P}<0.001)$ and lung cancer stage $(\mathrm{P}<0.001)$ were associated with the prognosis of breast cancer patients with second primary non-small cell lung cancer (NSCLC). However, for patients with second primary small cell lung cancer (SCLC), only the tumor stage $(\mathrm{P}<0.001)$ and age at the diagnosis $(\mathrm{P}<0.001)$ of SCLC were prognostic factors. ${ }^{11}$ However, they did not perform the multivariate Cox regression analysis to further verify the prognostic value of above parameters. Besides, Chen et al demonstrated that chemotherapy $\quad(\mathrm{HR}=6.182,95 \% \quad \mathrm{CI}: \quad 1.32-28.942$, $\mathrm{P}=0.021$ ), lymphovascular space invasion (LVSI) of pulmonary carcinoma $(\mathrm{HR}=22,95 \% \mathrm{CI}$ : $1.959-247.056, \mathrm{P}=0.012)$ and ground-glass opacity (GGO) ratio $<50 \% \quad(\mathrm{HR}=9.143$, 95\% CI: 1.055-79.261, $\mathrm{P}=0.045)$ were independent prognostic risk factors of multiple primary breast and lung cancer patients after analyzing 54 cases. Meanwhile, they also found that the chemotherapy for lung cancer $(\mathrm{HR}=25,95 \%$ CI: 4.47-139.82, $\mathrm{P}<0.001$ ), poorer differentiation of lung cancer $(\mathrm{HR}=8.125,95 \% \mathrm{CI}: 1.575-41.926, \mathrm{P}=0.012)$, pulmonary tumor $\geq 2 \mathrm{~cm}(\mathrm{HR}=15,95 \% \mathrm{CI}: 3.222-69.838, \mathrm{P}<0.001)$ LVSI of pulmonary carcinoma (13.67, 95\% CI: 1.271-146.99, $\mathrm{P}=0.031)$ and $\mathrm{GGO}$ ratio $<50 \% \quad(\mathrm{HR}=14.667,95 \% \quad \mathrm{CI}$ : 1.732-124.21, $\mathrm{P}=0.014$ ) were risk factor for recurrence. ${ }^{12}$

Thus, more relevant studies are urgently needed to investigate the prognostic characteristics of these patients and there are several fields worth exploring. First, it is known that some chemotherapeutic agents for breast cancer on lung cancer are the same, such as the docetaxel, paclitaxel and gemcitabine, ${ }^{13-}$ ${ }^{15}$ so if these chemotherapy drugs could show a better effect on improving the survival of lung cancer patients with breast cancer than other common chemotherapy drugs for lung cancer did? Second, it would be significative to build a prognostic model combining with a number of valuable parameters, which may greatly help with the evaluation of prognosis and formulation of treatment strategy.

There were several limitations in our study. First, the sample size of breast cancer patients with second lung cancer was relatively small. Second, some missing information of $\mathrm{pT}$ stage, pN stage, pTNM stage, ER, PR and HER-2 of breast cancer existed in our study, which limited the exploration for the prognostic value of these parameters. Third, we failed to verified the results of this study due to the lack of relevant data from other medical centers, but we intended to conduct a multi-center research to further testify above findings.

\section{Conclusion}

Differentiation status and pTNM stage were independent prognostic factors in operated breast cancer patients with second primary lung cancer. Meanwhile, the prognosis of this group of patients was worse than single primary lung cancer patients, 
which indicated that the medical history of breast cancer was also a prognostic risk factor of female lung cancer patients.

\section{Ethical Statement}

All procedures performed in studies involving human participants were in accordance with the ethical standards of the national research committee and the 1964 Helsinki Declaration and its later amendments or comparable ethical standards. Meanwhile, this study was approved by the regional committee of Sichuan University West China Hospital (ID: 2020-250). Written informed consent for the use and storage of information from the hospital database was obtained from each patient.

\section{Author Contributions}

All authors made a significant contribution to the work reported, whether that is in the conception, study design, execution, acquisition of data, analysis and interpretation, or in all these areas; took part in drafting, revising or critically reviewing the article; gave final approval of the version to be published; have agreed on the journal to which the article has been submitted; and agree to be accountable for all aspects of the work.

\section{Funding}

This study was funded by Sichuan Science and Technology Program (grant No. 2020YFS0252).

\section{Disclosure}

The authors have no conflicts of interest to declare.

\section{References}

1. DiMarzio P, Peila R, Dowling O, et al. Smoking and alcohol drinking effect on radiotherapy associated risk of second primary cancer and mortality among breast cancer patients. Cancer Epidemiol. 2018;57:97-103. doi:10.1016/j.canep.2018.10.002

2. Huang YJ, Huang TW, Lin FH, Chung $\mathrm{CH}$, Tsao CH, Chien WC. Radiation therapy for invasive breast cancer increases the risk of second primary lung cancer: a Nationwide Population-Based Cohort Analysis. J Thorac Oncol. 2017;12(5):782-790. doi:10.1016/ j.jtho.2017.01.021
3. Withrow DR, Morton LM, Curtis RE, Schonfeld SJ, Berrington de González A. Radiotherapy for ductal carcinoma in situ and risk of second non-breast cancers. Breast Cancer Res Treat. 2017;166 (1):299-306. doi:10.1007/s10549-017-4410-6

4. Mellemkjaer L, Friis S, Olsen JH, et al. Risk of second cancer among women with breast cancer. Int J Cancer. 2006;118(9):2285-2292. doi:10.1002/ijc. 21651

5. Mariotto AB, Rowland JH, Ries LA, Scoppa S, Feuer EJ. Multiple cancer prevalence: a growing challenge in long-term survivorship. Cancer Epidemiol Biomarkers Prev. 2007;16(3):566-571. doi:10.1158/1055-9965.EPI-06-0782

6. Hammond ME, Hayes DF, Dowsett M. American Society of Clinical Oncology/College of American Pathologists Guideline Recommendations for Immunohistochemical Testing of Estrogen and Progesterone Receptors in Breast Cancer (vol 134, pg 907, 2010). Arch Pathol Lab Med. 2010;134(8):1101. doi:10.5858/134.6.907

7. Kirova YM, De Rycke Y, Gambotti L, Pierga JY, Asselain B, Fourquet A; Inst Curie Breast Canc Study G. Second malignancies after breast cancer: the impact of different treatment modalities. $\mathrm{Br}$ $J$ Cancer. 2008;98(5):870-874. doi:10.1038/sj.bjc.6604241

8. Giuliano AE, Edge SB, Hortobagyi GN. Eighth edition of the AJCC cancer staging manual: breast cancer. Ann Surg Oncol. 2018;25 (7):1783-1785. doi:10.1245/s10434-018-6486-6

9. Kay FU, Kandathil A, Batra K, Saboo SS, Abbara S, Rajiah P. Revisions to the Tumor, Node, Metastasis staging of lung cancer (8th edition): rationale, radiologic findings and clinical implications. World J Radiol. 2017;9(6):269-279. doi:10.4329/wjr.v9.i6.269

10. Kim SW, Kong KA, Kim D-Y, Ryu YJ, Lee JH, Chang JH. Multiple primary cancers involving lung cancer at a single tertiary hospital: clinical features and prognosis. Thorac Cancer. 2015;6(2):159-165. doi:10.1111/1759-7714.12158

11. Wang R, Yin Z, Liu L, et al. Second primary lung cancer after breast cancer: a population-based study of 6269 women. Front Oncol. 2018;8:427. doi:10.3389/fonc.2018.00427

12. Chen -Y-Y, Huang Y-J, Huang H-K, et al. The prognostic factors of recurrence and survival in female patients with lung adenocarcinoma and breast cancer. J Cancer Res Clin Oncol. 2020;146(5):1299-1306. doi:10.1007/s00432-020-03162-5

13. You J, Wei S. Progress in resistance markers of commonly used chemotherapeutics for lung cancer and individualized medication. J Pract Oncol. 2008;01:82-86.

14. Buumba BM, Bhardwaj S, Kaur P. A critical review on recent development of techniques and drug targets in the management of breast cancer. Mini Rev Med Chem. 2021;21. doi:10.2174/ 1389557521666210126125200

15. Pathak M, Deo SVS, Dwivedi SN, Thakur B, Sreenivas V, Rath GK. Regimens of neo-adjuvant chemotherapy in the treatment of breast cancer: a systematic review \& network meta-analysis with PRISMANMA compliance. Crit Rev Oncol Hematol. 2020;153.

\section{Publish your work in this journal}

Cancer Management and Research is an international, peer-reviewed open access journal focusing on cancer research and the optimal use of preventative and integrated treatment interventions to achieve improved outcomes, enhanced survival and quality of life for the cancer patient.
The manuscript management system is completely online and includes a very quick and fair peer-review system, which is all easy to use. Visit http://www.dovepress.com/testimonials.php to read real quotes from published authors. 